\title{
Evaluation of Growth Potentials Of Three Cultivars Of Roselle (Habiscus Sabdariffa L.)As Influenced By Plant Population Density in Yola, Adamawa State, Nigeria
}

\author{
${ }^{1}$ Talaka, A. and ${ }^{2}$ Ugwegbulam, C. O. \\ Department of Agricultural Technology Federal Polytechnic, P.M.B. 05 Bali Taraba State, Nigeria.
}

\begin{abstract}
Field experiments were conducted during the cropping seasons of 2003 and 2009 on the Teaching and Research Farm of the Department of Crop production and Horticulture Federal University of Technology, Yola to evaluate the growth potentials of three cultivars of roselle (Hibiscus sabdarriffa L) (using two plant population densities of $60 \mathrm{~cm} x 30 \mathrm{~cm}$ and $80 \mathrm{~cm} \times 40 \mathrm{~cm}$. The experiment design was a Randomized Complete Block Design replicated four times. Parameters such as plant height at 3,5,7, plant height at harvests and number of leaves at 3,5,and 7 weeks after sowing were taken. The parameters measured at required height showed significant differences between cultivars and spacing. Plants with the tallest height of $58.75 \mathrm{~cm}$ were observed from cultivars 3 (Pink) at a spacing of 80cmx40cm in 2008 cropping season, while in 2009 cropping season, the tallest plant of $21.75 \mathrm{~cm}$ were recorded from pink cultivar at a spacing of $80 \mathrm{~cm} x 40 \mathrm{~cm}$. There was significant interaction at $P=0.05$ for plant height, number of leaves/plants at 3,5, and 7 weeks after sowing. There was also significant interaction between cultivars and spacing at $P=0.05$ for plant height and other parameters measured at 3, 5, and 7weeks after sowing. Due to high performance of cultivar (3) at a spacing of $80 x 40 \mathrm{~cm}$ it is recommended that cultivar 3 which is pink and spacing of 80x40cm in 2008 and 2009 cropping season be adopted in Yola and its environs for growth parameter of roselle
\end{abstract}

Keywords:- evaluation, growth, potential, cultivar, and plant population.

\section{Introduction:-}

One of the most important crop in the Malvaceae family is roselle (Hibiscus sabdarriffa L.). Difference species were first brought under cultivation in Africa in about $17^{\text {th }}$ Centuries and was developed as a fiber plant in South-East Asia (Purseglove 1987). In roselle, the vegetative period of the plant ranges from 130-180 days and rainfall requirement ranges from 20-30 ${ }^{\mathrm{OC}}$ (Purseglove, 1987 and Espig and Rehm, 1991). Hibiscus sabdarriffa can be sown or broadcasted; it can be drilled with an inter-row-spacing of $20-30 \mathrm{~cm}$ and spacing within the row of 5-10cm. (Espig and Rehm, 1991).

The spurious claims of the medicine at value of "Sobo" being antihypertensive and ant-diabetic have not been evaluated yet, however, the calcium contents known is to give protection against coronary-heat diseases (Isonguyo, 1997). Sobo drink can serve as a dietary supplement for older people. In some Middle East countries, Roselle is used mainly for its fiber, while the calyces are used in cold and warm beverages (Abu Tarboush et al, 1997). Roselle produces red, edible calyces which have been used for making Jelly, jam and beverages, and also for making food colorants (Mizukami et al, 1988). Obiefuna et al (1994), stated that aqueous extracts of Hibiscus sabdarriffa $\boldsymbol{L}$ leaves are traditionally used to treat coughs Rao, (1996), reported that roselle contains 19.8-22.3\% protein, 19.1-22.8\% fat, and 39.5\%-42.6\% fiber. He also stated that seeds of roselle contain minerals like phosphorus, magnesium and calcium.

The ultimate fiber dimensions of Hibiscus sabdarriffa L) compared favorable with similar known species for paper making. The breaking length of Hibiscus sabdariffa is $\mathbf{2 . 8 2} \mathbf{m m}$, while the pulp grammage equal to 61.00, the burst factor is 7.60. the degree of brightness however ranges from $85 \%-90 \%$ (Mizuka et at 1988).

\section{Materials And Methods:}

Field experiments were conducted at the Teaching and Research Farm of the Department of Crop production and Horticulture, Federal University of Technology, Yola during 2008 and 2009 cropping seasons. Yola is located in the North-East part of Nigeria. It lies between Latitude $9^{\circ} 14$ " and Longitude $12^{\circ} 38^{\text {" }}$ at an attitude of $185 \mathrm{~m}$ above sea level (Adebayo, 2001). The total rainfall between July and October of the two planting seasons were 555.7mm, and 407.3mm in 2008 and 2009 respectively ( Adebayo, 2001).

The experimental plot was ploughed using tractor and was harrowed by using hand hoe to make the experimental plot level and smooth for easy germination and establishment. The entire land for the experiment was bounded to prevent flooding and soil erosion. The area was marked out into plots using measuring tape. The 
experimental design was randomized to compete block design (RCBD) consisted of six treatments combinations and replicated four times.

Three cultivars of roselle were used, these includes white (C1), red (C2) and Pink (C3) with plant spacing of $60 \mathrm{~cm} \times 30 \mathrm{~cm}(\mathrm{~S} 1)$ and $80 \mathrm{~cm} \times 40 \mathrm{~cm}$ (S2). Each plot was measured at $3 \mathrm{mx} 3 \mathrm{~m}$, with one meter walk ways between plot and the replication. The total area for the experiment was $25 \mathrm{mx} 17 \mathrm{~m}\left(425 \mathrm{~m}^{2}\right)$. Seeds were sown on the $15^{\text {th }}$ and $18^{\text {th }}$ of July, 2008 and 2009 respectably. Two seeds were sowed hole and later thinned one plant par hole.

Parameter measured were plant height number of branches and number of leaves per plant at 3,5, and 7 weeks after sowing. Weight of fresh stem as well as number of branches were also taken. Data collected were subjected to analysis of variance as described by Gomez and Gomez (1987). Duncan's Multiple Range Test (DMRT) was used to separate means at 5\% probability level.

\section{Results And Discussion}

Mean effect of plant height at 3,5, and 7 weeks after sowing for 2008 and 2009 cropping seasons are presented in Table 1. Plant height were significantly affected by cultivars and spacing in 2008. Cultivar 1 (while) produced tallest plants of $11.08 \mathrm{~cm}$, at a spacing of $60 \mathrm{~cm} \times 30 \mathrm{~cm}$, while cultivar 3 (pink) produced tallest plants of $13.00 \mathrm{~cm}$ at a spacing of $80 \mathrm{~cm} \times 40 \mathrm{~cm}$ at 3 weeks after sowing. At 5 and 7 weeks after sowing, cultivar 3 produced tallest plants at the spacing of $80 \mathrm{~cm} \times 40 \mathrm{~cm}(58.75 \mathrm{~cm})$ in 2009 , cropping seasons, plant height at 3 weeks were the some with plant height at 5 weeks, Cultivar 1 produced tallest plants $(12.16 \mathrm{~cm})$ at a spacing of $60 \mathrm{~cm} \times 30 \mathrm{~cm}$ while cultivar 2 (red) at a spacing of $80 \mathrm{~cm} \times 40 \mathrm{~cm}$ produced tallest plants of $12,16 \mathrm{~cm}$. the difference in plant height by cultivars and spacing could be as a result of genetic and environmental factors as stated by Anwar et al---(1993) that eight cultivars of roselle were evaluated for their adaptability and fiber yield during the rainy seasons of 1978-1980 were highly significantly differences between genotypes and environment. the difference in stability were mainly the responses of genotypes to years.

Mean effect of plant height at harvest for 2008 and 2009 are presented in table 1 plant height at harvest was significantly affected by cultivars and spacing in 2008 and 2009 growing seasons cultivars 3 and plant spacing of $50 \mathrm{~cm} \times 40 \mathrm{~cm}$ produced tallest plants at harvest in $2008(58.75 \mathrm{~cm})$ while in 2009 , the tallest plant at harvest was 21.50 (11) at 60x30 spacing this is in line with William et al. (1986) who reported that roselle as an animal shrub could grow up to or more in height of $30_{-} 80 \mathrm{~cm}$ tall, with an alternate or palmate leaves divided into leaflet.

Mean effect of number of leaves for 2008 and 2009 presented in table 2. Number of leaves/plant was significantly affected by cultivars and spacing in 2008 and 2009 growing season Cultivar 3 and plant spacing of $60 \mathrm{~cm} \times 30 \mathrm{~cm}$ produced move number of leaves/plant (154.00) at 3 weeks while 2 and 3 at the spacing of $80 \mathrm{~cm} \times 40 \mathrm{~cm}$ produced the same number of leaves/plant at a spacing of $60 \mathrm{~cm} \times 30 \mathrm{~cm}$ while cultivars 2 and 3 at a spacing of $80 \mathrm{cmx} 40 \mathrm{~cm}$ produced the same number of leaves/plant (175.00). at 7 weeks, cultivars 2 and 3 produced more number of leaves $(980.75$ and 1152.25$)$ at a spacing of $80 x 40 \mathrm{~cm}$ and $60 x 30 \mathrm{~cm}$ respectively. In 2008 , cultivars 3 at a spacing of $60 \mathrm{~cm} \times 30 \mathrm{~cm}$ and $80 \mathrm{~cm} \times 40 \mathrm{~cm}$ produced more number of leaves/plant $(139.25$ and 104.00). at $80 \times 40 \mathrm{~cm}$, produced more number of leaves/per plant(187.25 and 139.25 and 104.00). at $80 x 40 \mathrm{~cm}$ produced more number of leaves/plant (187.25 and 151.50 respectively). The difference in number of leaves in cultivars and spacing could be attributed also to genetic and environmental factors and not spacing. Similar result was obtained by Juric et al. (1998) who conducted research in Ethiopic on difference spacing of $70 \times 100 \mathrm{~cm}, 60 \times 40 \mathrm{~cm}, 80 \times 40 \mathrm{~cm}$ and found out that the yield obtained were similar and concluded that the area was favorable for growing roselle. Bato et al, (1989) observed that there was large variability in yield between difference species as a result of variability of trial sites and season.

Mean effect of number of branches for 2008 and 2009 are presented in table 3 Number of branches was not significantly affected by cultivars and spacing in 2008 and 2009 growing season cultivars and plant spacing for 2008 and 2009 for all cultivars' and spacing did not show any significant difference. This might be because of genetic and environmental factors. Mean effect of weight of stem for 2008 and 2009 are presented in table 4 Weight of stem was not significantly affected by cultivars and plant spacing for 2008 and 2009 for all cultivars and spacing did not show any significant difference. This might be attributed to genetic and environmental factors. 
Evaluation Of Growth Potentials Of Three Cultivars Of Roselle ( Habiscus Sabdariffa L.)As

Table 1. Mean value of plant height at 3,5.7 weeks and at harvest after sowing in 2008 and 2009 Cropping Seasons

\begin{tabular}{|c|c|c|c|c|}
\hline Treatment & Plant height at 3 weeks (CM) & Plant Height at 5 weeks (CM) & Plant Height at 7 weeks (CM) & Plantheight at Harvest (CM) \\
\hline & 2008- 2009 combined & $2008 \quad 2009$ combined & $2008 \quad 2009$ combined & $2008 \quad 2009$ combined \\
\hline $\mathrm{C} 151$ & $11.08 \mathrm{C} * 9.00 \mathrm{~A} \quad 10.04 \mathrm{C}$ & $20.00 \mathrm{D}^{*} 12.16 \mathrm{~A} \quad 16.08 \mathrm{D}^{*}$ & $36.00 \mathrm{C}^{*} 12.33 \mathrm{C}^{*} \quad 24.16 \mathrm{D}^{*}$ & 45.00D $20.50 \mathrm{C}^{*} \quad 33.00 \mathrm{D}^{*}$ \\
\hline C2SI & $11.00 \mathrm{C}^{*} 9.00 \mathrm{~A} \quad 10.00 \mathrm{C}^{*}$ & $20.00 \mathrm{D} * 12.15 \mathrm{~A}$ & $41.75 \mathrm{~B}^{*} \quad 12.33 \mathrm{C}^{*} 27.00 \mathrm{D}^{*}$ & $48.75 \mathrm{C}^{*} 21.25 \mathrm{AB}^{*} 35.00 \mathrm{C}^{*}$ \\
\hline C3SI & $11.00 \mathrm{C}^{*} 9.00 \mathrm{~A} \quad 10.00 \mathrm{C}^{*}$ & $46.00 \mathrm{~A}^{*} 12.15 \mathrm{~A}$ & $45.75 \mathrm{~A}^{*} \quad 12.33 \mathrm{C}^{*} 29.04 \mathrm{~B}^{*}$ & $53.00 \mathrm{~B}^{*} 20.75 \mathrm{~B}^{*} \quad 36.87 \mathrm{~B}^{*}$ \\
\hline $\mathrm{C} 1 \mathrm{~S} 2$ & $19.19 \mathrm{~B} * 9.00 \mathrm{~A} \quad 10.45 \mathrm{~B}^{*}$ & $21.00 \mathrm{C}^{*} 12.12 \mathrm{~A} \quad 16.56 \mathrm{C}^{*}$ & $49.25 \mathrm{~A}^{*} \quad 12.35 \mathrm{C}^{*} 30.80 \mathrm{~A}^{*}$ & $58.00 \mathrm{~A}^{*} 21.00 \mathrm{BC} * 39.50 \mathrm{~A}^{*}$ \\
\hline $\mathrm{C} 2 \mathrm{~S} 2$ & $12.50 \mathrm{AB}^{*} 9.00 \mathrm{~A} \quad 10.75 \mathrm{~A}^{*}$ & $21.50 \mathrm{~B}^{*} \quad 12.16 \mathrm{~A} \quad 16.83 \mathrm{C}^{*}$ & $48.75 \mathrm{~A}^{*} \quad 12.37 \mathrm{~A}^{*} 30.56 \mathrm{~A}^{*}$ & $57.75 \mathrm{~A}^{*} 21.00 \mathrm{BC} * 39.37 \mathrm{~A}^{*}$ \\
\hline $\mathrm{C} 3 \mathrm{~S} 2$ & $13.00 \mathrm{~A}^{*} 9.00 \mathrm{~A} \quad 11.00 \mathrm{~A}^{*}$ & $22.00 \mathrm{~B}^{*} \quad 12.15 \mathrm{~A} \quad 17.07 \mathrm{~B}^{*}$ & 49.50A* $12.36 \mathrm{AB}^{*} 30.93 \mathrm{~A}^{*}$ & $58.75 \mathrm{~A}^{*} 21.75 \mathrm{~A}^{*} 40.25 \mathrm{~A}^{*}$ \\
\hline Interaction & $\begin{array}{lll}* & \mathrm{NS} & * \\
\end{array}$ & $\begin{array}{ll}* & \mathrm{NS} \\
\end{array}$ & $* \quad *$ & $\begin{array}{lll}* & * & *\end{array}$ \\
\hline
\end{tabular}

KEYS

$*=$ Significantly different

C1_C3=Cultivars 13

S1_S2= spacing 1 and 2

Table 2: Sean Value Of Number Of LearesPlant At 35 And 7 Weeks After Soving In 2008 Aad 2009 Cropping Seasons

No of leaves plant 3 weeks No of leares plant 5 meeks No of leares plant 7 weeks

\begin{tabular}{|c|c|c|c|c|c|c|c|c|c|}
\hline $\mathrm{CISI}$ & $\begin{array}{l}2008 \\
143.50 . \mathrm{B}^{*}\end{array}$ & $\begin{array}{l}2009 \\
123.50 A B^{7}\end{array}$ & $\begin{array}{l}\text { Combined } \\
13350 A B^{*}\end{array}$ & $\begin{array}{l}2008 \\
205.00 A B^{*}\end{array}$ & $\begin{array}{l}2009 \\
169.75 A^{7}\end{array}$ & $\begin{array}{l}\text { Combined } \\
18738 \mathrm{AB}^{*}\end{array}$ & $\begin{array}{l}2008 \\
256.05 A^{*}\end{array}$ & $\begin{array}{l}2009 \\
175.75 \mathrm{~A}\end{array}$ & $\begin{array}{l}\text { Combired } \\
673.00 \mathrm{~A}\end{array}$ \\
\hline $\mathrm{C} 2 \mathrm{SI}$ & $143.50 A B^{*}$ & $13350 \mathrm{~A}^{*}$ & $13850 A^{* *}$ & $205.00 A B^{*}$ & $18725 \mathrm{~A}^{x}$ & $196.13 \mathrm{~A}^{*}$ & $261.00 . \mathrm{AB}^{*}$ & $22550 \mathrm{~A}^{*}$ & $65625 \mathrm{~A}$ \\
\hline $\mathrm{C} 3 \mathrm{SI}$ & $154.00 \mathrm{~A}^{\mathrm{x}}$ & $13925 A^{*} B^{*}$ & $143.13 A^{* *}$ & $220.00 \mathrm{~A}^{x}$ & $177.75 \cdot \mathrm{B}^{*}$ & $198.88 \mathrm{~A}^{*}$ & $278.33 A^{*}$ & $30850 \mathrm{~A}$ & $730.38 \mathrm{~A}$ \\
\hline $\mathrm{CIS2}$ & $122.50 B C^{*}$ & $875 B^{2}$ & $105.00 C^{* 1}$ & $175.00 B C^{*}$ & $11650 \mathrm{~B}^{2}$ & $147.75 C^{*}$ & $231.41 B C^{2}$ & $159.75 \mathrm{C}$ & $58038 . \mathrm{AB}$ \\
\hline $\mathrm{C} 2 \mathrm{S2}$ & $122.50 \mathrm{BC} *$ & $9450 . B^{2}$ & $108.50 B C^{* *}$ & $175.00 B C^{*}$ & $125.75 . \mathrm{B}^{*}$ & $149.38 B C^{2}$ & $233.30 \mathrm{BC}^{*}$ & $228.75 \mathrm{AB}$ & $60475 \mathrm{AB}$ \\
\hline $\begin{array}{l}\text { C3S2 } \\
\text { Interactioe }\end{array}$ & $\begin{array}{l}112.00 \mathrm{C}^{\mathrm{a}} \\
=\end{array}$ & $\begin{array}{c}10400 A B^{3} \\
*\end{array}$ & $\begin{array}{c}10850 B C^{* *} \\
* *\end{array}$ & $\begin{array}{r}160.00 C^{*} \\
=\end{array}$ & $\begin{array}{c}15750 A B^{*} \\
*\end{array}$ & $\begin{array}{c}155.75 \mathrm{BC} \\
=\end{array}$ & $\begin{array}{r}22020 C^{*} \\
*\end{array}$ & $\begin{array}{l}214.75 \mathrm{~B} \\
\mathrm{NS}\end{array}$ & $\begin{array}{l}592.38 . A B \\
\mathrm{NS}\end{array}$ \\
\hline
\end{tabular}

KEIS

$*=$ Significantly different

** $=$ High significantly different

$\mathrm{NS}=$ Not Significant

CL. $\mathrm{C} 3=$ Coltive $1-3$

Table 3: Mean Value Of Number Of Branches/Plant At 35 . And 7 Weeks After Soring In 2008 And 2009 Cropping Seasons No' of branches plant 3weeks No of branches plant 5neeks No of branches plant at. ? weeks neight of stems

\begin{tabular}{|l|l|l|l|l|l|l|l|l|l|l|l|l|}
\hline C1S1 & 2008 & 2009 & $\begin{array}{l}\text { Combined } \\
92.88\end{array}$ & $\begin{array}{l}2008 \\
154.00\end{array}$ & $\begin{array}{l}2009 \\
104.50\end{array}$ & $\begin{array}{l}\text { Combined } \\
129.25\end{array}$ & $\begin{array}{l}2008 \\
2982\end{array}$ & $\begin{array}{l}2009 \\
143.50\end{array}$ & $\begin{array}{l}\text { Combined } \\
220.88\end{array}$ & $\begin{array}{l}2008 \\
0.40\end{array}$ & $\begin{array}{l}2009 \\
0.57\end{array}$ & $\begin{array}{l}\text { Combiced } \\
0.48\end{array}$ \\
\hline C2S1 & 100.00 & 90.00 & 95.00 & 154.00 & 120.50 & 137.25 & 209.00 & 321.50 & 265.25 & 0.63 & 0.37 & 0.50 \\
\hline C3S1 & 105.00 & 90.75 & 97.38 & 143.50 & 121.00 & 137.50 & 275.50 & 163.25 & 220.38 & 0.45 & 0.42 & 0.43 \\
\hline C1S2 & 95.00 & 88.50 & 91.75 & 143.50 & 104.75 & 124.13 & 218.75 & 137.75 & 178.25 & 0.39 & 0.35 & 0.48 \\
\hline C2S2 & 9750 & 93.00 & 92.25 & 143.50 & 109.95 & 126.63 & 259.00 & 154.00 & 206.50 & 0.62 & 0.35 & 0.48 \\
\hline C3S2 & 95.00 & 80.75 & 87.38 & 143.50 & 99.25 & 121.38 & 227.75 & 139.00 & 183.38 & 0.77 & 0.68 & 0.72 \\
Interactioc & $\mathrm{NS}$ & $\mathrm{NS}$ & $\mathrm{NS}$ & $\mathrm{NS}$ & $\mathrm{NS}$ & $\mathrm{NS}$ & $\mathrm{NS}$ & $\mathrm{NS}$ & $\mathrm{NS}$ & $\mathrm{NS}$ & $\mathrm{NS}$ & $\mathrm{NS}$ \\
\hline
\end{tabular}

$\mathrm{Ker}$

NS=Not Sigificant

Cl-co $=$ Cultirars $1-3$

SISI $=$ Spacing 1 ad 2

\section{Conclusion}

Based on the result of this study, it can be recommended that cultivars 3 (pink) produced tallest plants in $58.75 \mathrm{~cm}$ at a spacing of $80 \mathrm{~cm} \times 40 \mathrm{~cm}$ in 2008 cropping seasons. Also in 2009 cropping season, cultivars 3 (pink) produced the tallest plants of $21.75 \mathrm{~cm}$ at spacing of $80 \mathrm{~cm} \times 40 \mathrm{~cm}$. Also in number of leaves, cultivars 3 (pink) produced the highest number of leaves $(11.52 .25$ ) at a spacing of 60x30cm in 2008 and 2009, the some cultivar 3 (pink) produced 308. 50 at a spacing of $60 \times 30 \mathrm{~cm}$. Therefore, cultivar 3(pink) is recommended for cultivation by farmers in Yola and it's envious for growth parameters.

\section{References}

[1] Abu- Tarboush, H.M, Ahmed, S.A.B. and Atkahtain, H.A. (1977). Some nutritional and functional properties of Karkade (Hibiscus sabdarriffa L) seed products. The department of food science, college of Agriculture, King Sand University, Riyadh-Saudi-Arabia 74 ; (3) 352-355.

[2] Adebayo,A.A, (2001); Temperature variability and out break of meningitis and measles in Yola, Nigeria. Global Journal of pure and Applied science Vol.7No 1, 133: 135. 
[3] Anwar,R, Bhatti, M.S, Afzal, M na Rabbiani, A, (1993): Collection fiber plant germsplant in Pakistan. Plant - Genetic - resources Newslethir, 94,-95-21-25.

[4] Bato,S.M, Malijan, O D. Lovenzana, O.J, Pere, Z.R.I, Melchor, J.P, Leysa, P.S. and Embra-Jador (1989). Verification traint of an integrated pest management program for control of Asian comporer. Terminal report.

[5] UPLB - NCPC_ PCARRD research project.

[6] Espig G, and Rehm, S. (1991). The cultivated plant of the tropic and sub Tropic (Cultivation economic value, utilization) Verlag Jost Margraf $1^{\text {st }}$ edition . Priese GMBH, Berlin Germany. Pp.347_ 349.

[7] Gomez, K.A and Gomez, K.A (1987). Statistical procedure for Agricultural Research $2^{\text {nd }}$ Edition Pp 680

[8] Isonguyo, E.N (1997) Appraisal Local Processing Technique and Nutrition value of sobo drink. Food science Department, Federal University of Technology, Yola Pp.3-4

[9] Jurici., zugec, I, Knezevic, N. and Josipovic.M. (1998). Influence of row spacing on yield of Roselle (Hibiscus Sabdariffa L.) in Ethiopia. Poljooprivreda. 4; (2)21_26.

[10] Mizukami, H. Tomita, K.; Ohashi, H.; Hiraoka, N (1988): Anthocranin production in callus Cultures of Roselle (Hibiscus sabdariffa l) Journal of Pharmaceutical Science; 7; (7)553__556.

[11] Obiefuna, .C.M.; Owolabi; O.A.; Adegunloye ; B.J.; Obiefuna; I.P. and Sofola, O.A.(1994). The petal Extract of Hibiscus. Sabdariffa produces relaxation of isolated rat aorta. Journal of Phamacognosy, 32; (1) $69 \_74$.

[12] Purseglove, J.W. (1987). Tropical crops (Dicotyledons) Longman, London Pp 370__ 374.

[13] Rao, P.U. (1996): Nutrient Composition and biological evaluation of Mesta (Hibiscus Sabdariffa L) seeds plant foods for human Nutrition. 49,(1), $27 \_37$. 